\title{
ON THE TAXONOMIC STATUS OF SPECIES \\ FROM THE GROUP «MYOTIS NATTERERI» (CHIROPTERA, VESPERTILIONIDAE) IN THE EASTERN CAUCASUS
}

\author{
Dmitriy G. Smirnov ${ }^{1, *}$, Vladimir P. Vekhnik², Gadzhibek S. Dzhamirzoyev ${ }^{3,4}$, Sergey V. Titov ${ }^{1}$ \\ ${ }^{1}$ Penza State University, Russia \\ *e-mail: eptesicus@mail.ru \\ ${ }^{2}$ Zhiguli State Nature Biosphere Reserve, Russia \\ e-mail:vekhnik@mail.ru \\ ${ }^{3}$ Tembotov Institute of Ecology of Mountain Territories of RAS, Russia \\ ${ }^{4}$ Dagestan State Nature Reserve, Russia \\ e-mail:dzhamir@mail.ru
}

Received: 03.04.2020. Revised: 05.08.2020. Accepted: 14.08.2020.

\begin{abstract}
In Russia, Myotis nattereri was considered as a monotypic species, of which its range is divided into two parts.. One of them is the northern fragment consisting of Central Russia and the Urals, while the southern part of its range includes the Caucasus and Crimea. On the basis of morphological and molecular-genetic data, the taxonomic status of its Caucasian forms is discussed. In the Eastern Caucasus (Republic of Dagestan, Russia), we caught Myotis animals related to the group of «Myotis nattereri» species, similar to specimens of the West Asian Myotis cf. tschuliensis on the basis of skull size measurements. A comparison analysis showed that, outwardly, $M$. cf. tschuliensis 2 individuals are highly similar to specimens from Central Russia. However, these animals have some differences in the ear structure, os penis, attachment of the posterior edge of the wing membrane to the foot, and in the ratio of cilia lengths to bristles on the free edge of the tail membrane. The more reliable differences between $M$. cf. tschuliensis 2 animals and $M$. nattereri s.str. specimens were revealed on the basis of craniometric studies, but the complete confirmation of the species' independence of Caucasian specimens was obtained using the analysis of mtDNA sequences. According to phylogenetic constructions, Dagestan specimens designated by us as $M$. cf. tschuliensis 2 , formed a well separated sister line in relation to the clade of Caucasian forms: $M$. schaubi and $M$. cf. tschuliensis 1 ( $p$-distance: 7.4-7.0\%). There are no reliable morphological differences between $M$. cf. tschuliensis 2 and $M$. cf. tschuliensis 1 . Prior to genetic studies of $M$. tschuliensis specimens, we suggest using an open nomenclature for the East Caucasian form. If specimens designated as $M$. cf. tschuliensis 1 , originated from the Near East, are genetically identical to the $M$. cf. tschuliensis specimens from its type location in Turkmenistan, then Dagestan bats designated as $M$. cf. tschuliensis 2 should be considered as a new, undescribed species.
\end{abstract}

Key words: cryptic species, Myotis cf. tschuliensis, Natterer's bat, Republic of Dagestan, taxonomy

\section{Introduction}

Previously, Myotis nattereri s.l. (Kuhl, 1817) was considered as a species with a wide Western Palearctic distribution (Horáček \& Hanak, 1984; Simmons, 2005; Grimmberger \& Rudolf, 2009). Molecular genetic studies conducted over the last 15 years using mitochondrial and nuclear markers demonstrated that $M$. nattereri is a complex consisting of at least eight well-separated lines, presumably of species rank (Fig. 1). The first line is represented by M. nattereri s.str., which is common in Central and Northern Europe, including European Russia. The second line is represented by a recently described species, $M$. crypticus Ruedi et al., 2019, found in the North of the Iberian Peninsula (southern France, northern Spain), and probably in Switzerland and Austria (Mayer et al., 2007; Salicini et al., 2011, 2013; Juste et al., 2019). The third line is represented by M. escalerai Cabrera, 1904, whose range covers the entire Iberian Peninsula (Ibáñez et al., 2006). The fourth line is represented by another recently described species from
North-Western Africa (Morocco), M. zenatius Ibáñez et al., 2019 (García-Mudarra et al., 2009; Salicini et al., 2011, 2013; Juste et al., 2019). The fifth line is represented by M. schaubi (Kormos, 1934) distributed in arid habitats from Transcaucasia to Western Iran (Ruedi \& Mayer, 2001; Jones et al., 2006; Salicini et al., 2011, 2013; Çoraman et al., 2019; Juste et al., 2019). The sixth line from Corsica and possibly southern Italy is represented by a yet undescribed form, designated as «M. sp. C» (Puechmaille et al., 2012). The seventh line is originated from Transcaucasia and North-Eastern Turkey. It was suggested to identify it as M. tschuliensis Kuzyakin, 1935 (Jones et al., 2006; Çoraman et al., 2019). However, animals distributed within the type area of $M$. tschuliensis have never been studied genetically before. Hence, we suggested to designate the specimens from Turkey and Transcaucasia as M. cf. tschuliensis 1. Finally, another separate line is probably represented by $M$. hoveli Harrison, 1964, described from South-Eastern Anatolia and Israel (Çoraman et al., 2019). 


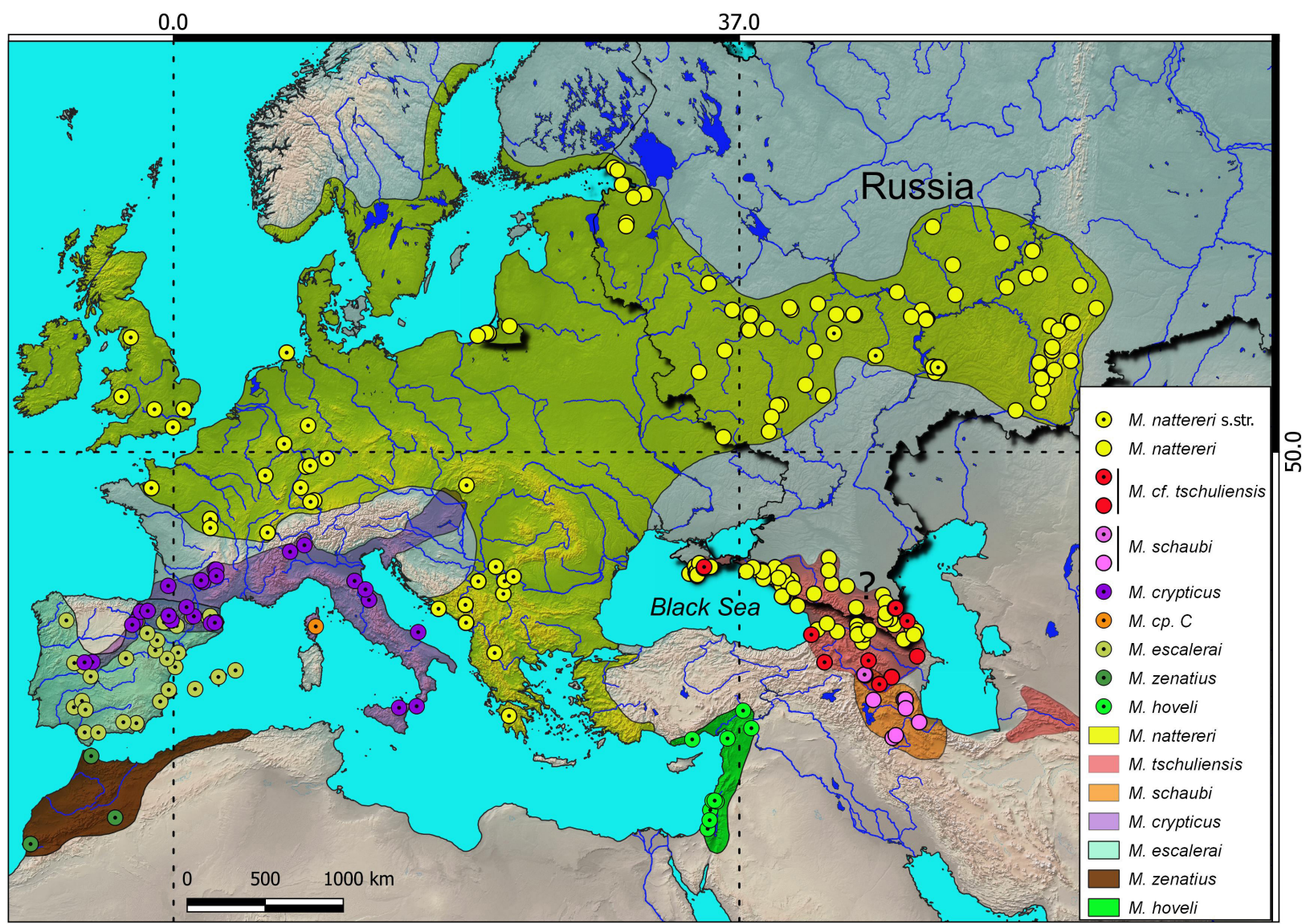

Fig. 1. Distribution of taxa of the Myotis nattereri complex in the Western Palaearctic. Circles with a dot indicate the locations on the basis of genetically typed specimens from both GenBank and our personal data (Central Russia, Dagestan). Empty circles indicate locations on the basis of original materials and literature data. The Russian border is indicated by a relief line.

In Russia, M. nattereri was considered as a monotypic species (Ilyin et al., 2002; Kruskop, 2012), having a disjunctive range. It is distributed mainly in the North-Western, Central and Central-Chernozem regions of European Russia, Middle Volga Region, Middle and Southern Urals, while the southern limit of the species range is confined to the southern border of the forest-steppe zone (Ilyin et al., 2002; Bogdarina \& Strelkov, 2003; Snitko, 2011; Artaev \& Smirnov, 2016). The second part of the species range covers the area of the Crimea, Stavropol Upland and the Caucasus (Gazaryan, 2002; Ilyin et al., 2002; Red Data Book of the Republic of Crimea, 2015; Smirnov et al., 2019a). This area is separated from the northern part of the species range by a wide strip of arid treeless plains. Perhaps, both parts of the species range have been isolated for so long time that their taxonomical compositions may not be identical. On the other hand, the southern fragment of the species range is geographically close to the West Asian forms of the M. nattereri s.l. complex, which does not exclude closer genetic relationships with them.
We had a number of $M$. nattereri s.l. specimens from the Eastern Caucasus (Republic of Dagestan, Russia). Being initially supposed to be a nemoral forest species, they were found in atypical arid treeless habitats (Smirnov et al., 2019b). All the examined animals had only small morphological differences from the specimens from Central Russia. Previously, assumptions were made about possible records of the Trans-Caucasian $M$. schaubi in the south of Dagestan (Pavlinov et al., 2002) and the separate position of pre-Caucasian populations (Kruskop, 2012). In addition, some authors (e.g., Kozhurina, 2009) believed that a form of M. n. tschuliensis Kuzyakin, 1935, described from southern Turkmenistan, is known in Dagestan and presumably in the Central Caucasus. However, previously there were no attempts to conduct a qualitative morphological description of specimens from the Eastern Caucasus, and to identify the criteria on the basis of which they could be identified.

In this paper, we aimed to identify the differences between the Eastern Caucasian bat specimens of the "Myotis nattereri» group (preliminary designated as M. cf. tschuliensis 2) and M. nat- 
tereri from Central Russia with establishing their taxonomic status.

\section{Material and Methods}

Bat specimens were caught in nets or found in potential daytime shelters in 1995-2019. They were measured for conducting this study. A significant part of these specimens (more than 90\%) were captured in the following Protected Areas: Dagestan State Nature Reserve, Zhiguli State Nature Biosphere Reserve, Mordovia State Nature Reserve, and Samarskaya Luka National Park. All captured animals were examined and measured. From some of these individuals, we used materials for molecular genetic studies (perforation of the flying membrane). These animals were ringed and after a little overexposure released at the places of capture. The animals were captured and sampled in accordance with the guidelines for the use of wild mammals in scientific research (Sikes \& Gannon, 2011). In the study, we used skulls from four dead animals from colonies of Dagestan, as well as M. nattereri specimens from Central Russia (Samarskaya Luka National Park, Zhiguli State Nature Reserve), stored in the collection funds of the Department of Zoology and Ecology of the Penza State University (PSU) (Appendix 1).

\section{Morphometric analysis}

The following main external traits were measured: body length (L), tail length $(\mathrm{C})$, forearm length $(\mathrm{R})$, ear length $(\mathrm{Au})$, and tragus length $(\mathrm{Tr})$. For craniometric analysis, we measured the following 17 traits of each scull: total length (TL), condylobasal length (CBL); zygomatic width (ZW), width at mastoids (MW); neurocranium height $(\mathrm{H})$, neurocranium width $(\mathrm{W})$; interorbital width (SW); palate length (PL); rostrum width (WR); crown-measured width between the outer margins of upper canines (CC); crown-measured width between outer margins of the third molar (MM) width; length of upper tooth row $\left(\mathrm{CM}^{3}\right)$, length of lower tooth row $\left(\mathrm{CM}_{3}\right)$; total length of the upper $\left(\mathrm{IM}^{3}\right)$ and lower $\left(\mathrm{IM}_{3}\right)$ tooth row, i.e. from the front edge of the incisors to the back side of a third molar; mandibular length (LMD), mandibular height (HMD). All measurements were performed using an electronic caliper with an accuracy of 0.01 $\mathrm{mm}$. The obtained measurements were processed using the STATISTICA software (StatSoft, Inc., 2001) using data reduction methods (Principal Component Analysis) and classification with training (Discriminant Function Analysis). Prepara- tion of os penis samples and their processing have been carried out according to White (1951), Frilei (1947), Smirnov (2000).

\section{Molecular analysis}

The mitochondrial cytochrome b (cytb) gene was used for molecular genetic analysis. Genomic DNA was isolated from tissue samples stored in $96 \%$ ethanol using standard method of proteinase $\mathrm{K}$ lysis, phenol-chloroform deproteinisation, and precipitation with cooled absolute ethanol in the presence of sodium acetate (Sambrook et al., 1989). The following primers were used to amplify and sequence the complete cytb gene: F1 (5'CCA CGA CCAATG ACA YGA AAA-3') and R1 (5'-CCT TTT CTG GTT TAC AAG ACC AG-3') (Benda et al., 2016). The reaction mixture for PCR $(25 \mu \mathrm{l})$ contained $50-100 \mathrm{ng}$ of DNA, $0.5 \mu \mathrm{m}$ of each primer, $0.2 \mathrm{~mm}$ dNTPs, $1.5 \mathrm{~mm} \mathrm{MgCl}, 2.5 \mu \mathrm{l}$ $10 \times$ PCR buffer (10 mm Tris-HCl, $\mathrm{pH} \mathrm{8.3,50} \mathrm{mm}$ $\mathrm{KCl}$ ) and 2 units of Taq polymerase (Thermo Scientific). The amplification reaction was performed under the following conditions. Initial denaturation processed during $3 \mathrm{~min}$. at $94^{\circ} \mathrm{C}$. Then we performed 35 cycles under the following conditions: denaturation during $40 \mathrm{~s}$. at $94^{\circ} \mathrm{C}$, annealing during $40 \mathrm{~s}$. at $50^{\circ} \mathrm{C}$, synthesis during $90 \mathrm{~s}$ at $65^{\circ} \mathrm{C}$, final synthesis during $5 \mathrm{~min}$. at $65^{\circ} \mathrm{C}$. PCR products were tested using $6 \%$ PAGE. Sequencing was performed using a set of reagents for DNA sequencing BigDye Terminator v. 3.1 Cycle Sequencing Kit and ABI PRISM 3500 genetic analyser (Applied Biosystems). The primers for cytb sequencing were the same as for PCR amplification. The obtained sequences have been deposited in GenBank (Acc. No.: MT992623-MT992637).

Sequences were edited manually using software CromasPro 13.3 (Technelysium, Australia) and BioEdit V. 7.0 (Hall, 1999), and aligned in MEGA7. 0.26 (Kumar et al., 2016). For comparison, we used previously published and available in GenBank (https://www.ncbi.nlm.nih.gov/genbank/) sequences of the same gene from different species' forms of the group M. nattereri s.l. (Appendix 2). Phylogenetic relationships were evaluated using neighbour-joining (NJ) and maximum likelihood (ML) methods. The model that best describes the evolution of the studied sequences was selected in jModelTest 2.1.7 (Darriba et al., 2012) on the basis of the Bayesian information criterion (BIC). The best replacement model was $\mathrm{TN} 93+\mathrm{G}+\mathrm{I}(-\ln \mathrm{L}=6289.18, \mathrm{BIC}=14689.15) . \mathrm{In}$ addition, a Bayesian analysis (BI) was performed 
using MrBayes 3.1.2 (Ronquist \& Huelsenbeck, 2003). We used the following launch parameters: two simultaneous launches of 1000000 generations with the frequency of parameters recording every 100 generations. The first 25\% of the generation was excluded as training ones. The cytb gene sequences of Eptesicus nilssonii and E. serotinus were used as an external group (GenBank: AF376836 and EU751000.1). The genetic distances ( $\mathrm{p}$-distance) were calculated using MEGA 7.0.26. When visualising the phylogenetic relationships, the topology of the NJ-tree was used as the basis. Statistical confidence of the branching order was estimated using bootstrap analysis of 1000 alternative trees (bootstrap percentage, \%) and Bayesian a posteriori probabilities (\%). The median network of mitochondrial haplotypes was constructed in the software PopART (Leigh et al., 2015) using the TCS algorithm (Clement et al., 2000).

\section{Morphology}

\section{Results}

The fur colour of Myotis $\mathrm{cf}$. tschuliensis 2 is similar to specimens from Central Russia (Fig. 2 ). Slight differences concern only the colour of the auricles, which was paler in most of the examined individuals. In addition, the upper half of the back edge of ears had a well-defined clipping, which probably contributes to the ear's folding. Individuals from the northern part of the species range had the same clipping, but it was not so recognisable.
To find the possible external differences, we paid attention to the character of attachment of the posterior edge of the plagiopatagium to the foot (Fig. 3). Dagestan bats have a membrane attached to the base of the outer finger, while $M$. nattereri specimens from the northern part of the species range have the attachment closer to the middle of the metatarsal. In addition, we found differences in the size of cilia and bristles located on the free edge of the uropatagium between tail and spur. In Myotis cf. tschuliensis 2 , the cilia length $(\mathrm{M} \pm \mathrm{SD}: 1.7 \pm 0.2$ $\mathrm{mm}$; min-max: $1.4-2.1 \mathrm{~mm}$ ) is almost always more than $1.4 \mathrm{~mm}$, whereas $M$. nattereri has lower values $(\mathrm{M} \pm \mathrm{SD}: 1.1 \pm 0.2 \mathrm{~mm}$; min-max: 0.8-1.4 mm). On the contrary, the bristles had higher length values in $M$. nattereri $(\mathrm{M} \pm \mathrm{SD}$ : $1.1 \pm 0.2 \mathrm{~mm}$; $\min -\max$ : $0.8-1.4 \mathrm{~mm})$ than in $M$. cf. tschuliensis $2(\mathrm{M} \pm \mathrm{SD}$ : $0.7 \pm 0.03 \mathrm{~mm}$; min-max: $0.7-0.8 \mathrm{~mm}$ ).

With a wide overlap of measurements, East Caucasian specimens were on average slightly larger than $M$. nattereri in terms of external morphometric traits (Table 1). The most considerable differences were found in the total body length and the forearm length. However, these differences were not statistically significant, which does not allow us to unambiguously identify the species on the basis of these morphometric traits.

The skull of Myotis cf. tschuliensis 2 did not differ from the M. nattereri skull (Fig. 4). Its neurocranium is rounded and high, and in the frontalnasal section, the upper line of the profile is steeply curved. The rostral part is wide at its base and strongly narrowed towards the end.
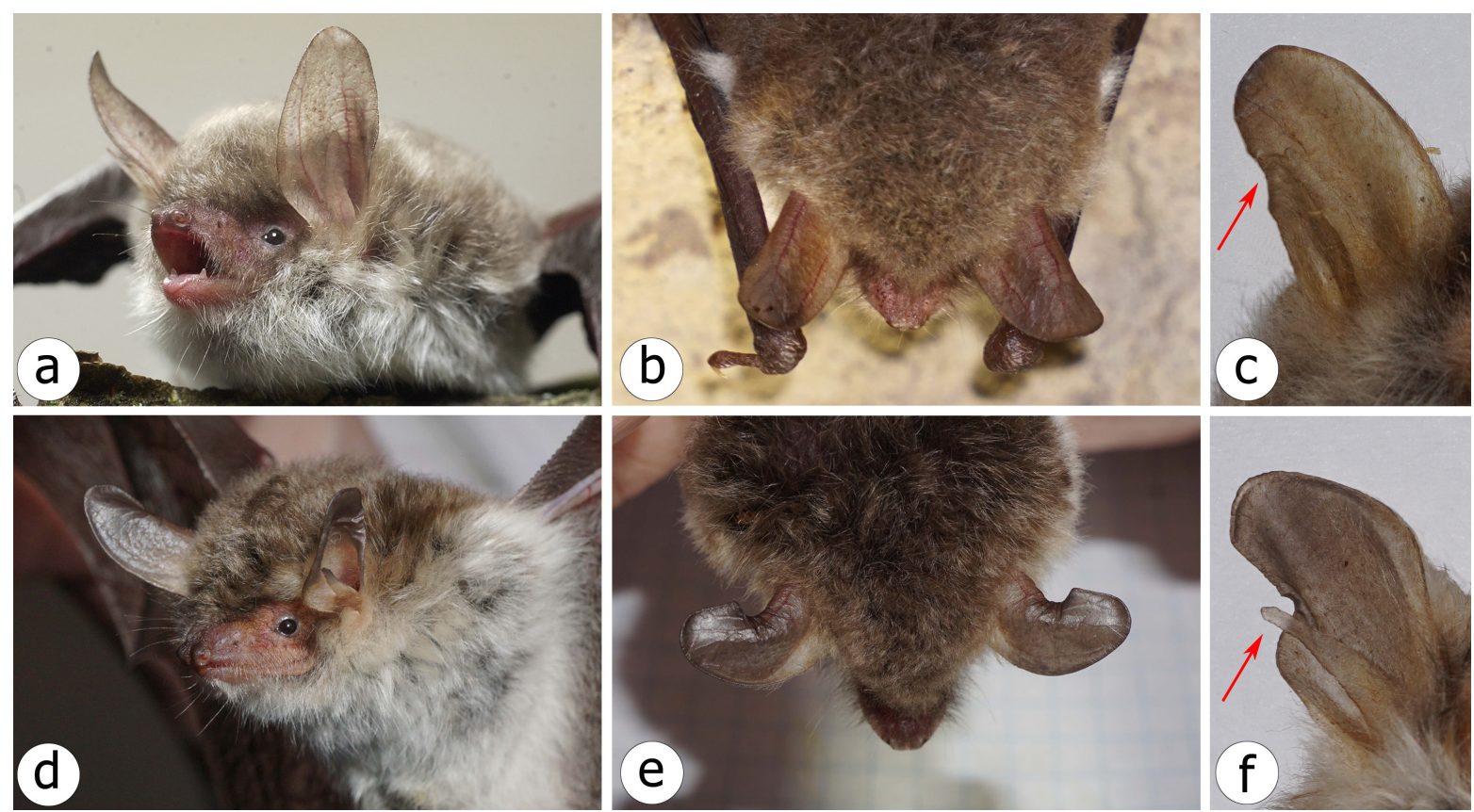

Fig. 2. Myotis nattereri (a, b, c) and $M$. cf. tschuliensis 2 (d, e, f). Arrows show ear clippings. 

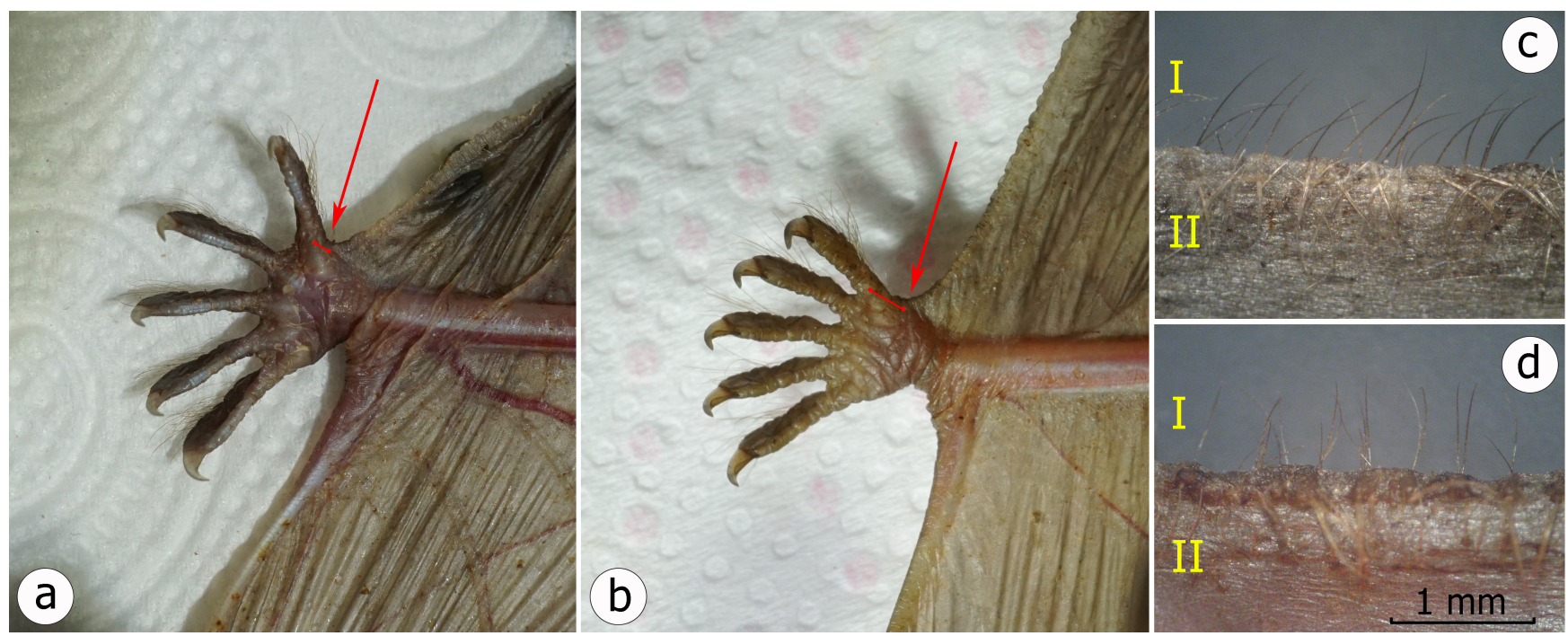

Fig. 3. The character of plagiopatagium attachment to the foot (demonstrated by arrows) (a, b), and a free edge of the uropatagium (I - cilia, II - bristles) (c, d) in Myotis cf. tschuliensis 2 (a, c) and Myotis nattereri (b, d).

Table 1. The main biometric measurements of the body and skull of Myotis nattereri (Central Russia), M. cf. tschuliensis 2 (Dagestan), M. cf. tschuliensis 1 (Turkey, Azerbaijan) and M. schaubi (Iran)

\begin{tabular}{|c|c|c|c|c|c|c|c|c|c|c|c|c|c|c|c|c|}
\hline \multirow[t]{2}{*}{ Trait } & \multicolumn{4}{|c|}{ Myotis nattereri } & \multicolumn{4}{|c|}{ Myotis cf. tschuliensis 2} & \multicolumn{4}{|c|}{$\begin{array}{l}\text { Myotis cf. tschuliensis } 1 \\
\text { (Benda et al., 2011) }\end{array}$} & \multicolumn{4}{|c|}{$\begin{array}{c}\text { Myotis schaubi } \\
\text { (Benda et al., 2012) }\end{array}$} \\
\hline & $n$ & M & $\min -\max$ & SD & $n$ & M & $\min -\max$ & SD & $n$ & M & $\min -\max$ & SD & $n$ & M & $\min -\max$ & SD \\
\hline $\mathrm{L}$ & 19 & 45.1 & $40.7-48.4$ & 2.4 & 10 & 46.6 & $44.6-48.1$ & 1.8 & - & - & - & - & 2 & 50.5 & $48-53$ & 2.4 \\
\hline $\mathrm{C}$ & 17 & 44.5 & $40.3-48.1$ & 1.9 & 10 & 43.5 & $41.9-45.1$ & 1.6 & - & - & - & - & 2 & 48.8 & $48-49$ & 0.5 \\
\hline $\mathrm{R}$ & 35 & 40.2 & $38.9-42.6$ & 0.9 & 10 & 41.6 & $41.0-43.7$ & 1.1 & 5 & 41.02 & $39.2-41.9$ & 1.1 & 2 & 42.8 & $41.3-44.1$ & 1.0 \\
\hline $\mathrm{Au}$ & 19 & 17.3 & $15.1-19.7$ & 1.2 & 10 & 17.7 & $17.3-18.4$ & 0.6 & - & - & - & - & 2 & 20.3 & $19.2-21.3$ & 1.1 \\
\hline $\operatorname{Tr}$ & 19 & 10.9 & $10.4-11.2$ & 0.3 & 10 & 11.0 & $10.8-11.3$ & 0.3 & - & - & - & - & 2 & 11.2 & $10.5-11.9$ & 0.6 \\
\hline $\mathrm{TL}$ & 19 & 15.8 & $15.3-16.8$ & 0.35 & 4 & 16.2 & $16.0-16.5$ & 0.21 & 4 & 16.1 & $15.6-16.6$ & 0.41 & 2 & 17.2 & $16.8-17.4$ & 0.21 \\
\hline CBL & 19 & 14.8 & $14.2-15.1$ & 0.26 & 4 & 15.2 & $15.0-15.3$ & 0.13 & 4 & 15.2 & $14.7-15.6$ & 0.36 & 2 & 16.1 & $15.7-16.2$ & 0.19 \\
\hline ZW & 19 & 9.75 & $9.4-10.0$ & 0.17 & 4 & 10.13 & $9.9-10.4$ & 0.22 & - & - & - & - & 2 & 10.72 & $10.3-10.9$ & 0.21 \\
\hline MW & 19 & 7.77 & $7.5-8.0$ & 0.14 & 4 & 7.98 & 7.9-8.2 & 0.15 & - & - & - & - & 2 & 8.24 & $7.92-8.52$ & 0.22 \\
\hline $\mathrm{H}$ & 19 & 7.05 & $6.7-7.4$ & 0.13 & 4 & 7.10 & $6.9-7.3$ & 0.16 & - & - & - & - & - & - & - & - \\
\hline W & 19 & 7.89 & $7.7-8.0$ & 0.11 & 4 & 8.10 & $8.0-8.2$ & 0.08 & - & - & - & - & - & - & - & - \\
\hline PL & 19 & 7.22 & $6.8-7.8$ & 0.27 & 4 & 7.10 & $6.8-7.3$ & 0.22 & - & - & - & - & - & - & - & - \\
\hline WR & 19 & 4.02 & $3.8-4.2$ & 0.09 & 4 & 4.33 & $4.1-4.5$ & 0.17 & - & - & - & - & - & - & - & - \\
\hline SW & 19 & 3.84 & $3.6-4.1$ & 0.14 & 4 & 3.90 & $3.8-4.1$ & 0.08 & 4 & 3.59 & $3.49-3.71$ & 0.10 & 2 & 4.03 & $3.82-4.18$ & 0.14 \\
\hline $\mathrm{CC}$ & 19 & 3.92 & $3.7-4.1$ & 0.12 & 4 & 4.10 & $4.0-4.2$ & 0.08 & 4 & 4.10 & $4.06-4.13$ & 0.04 & 2 & 4.46 & $4.27-4.54$ & 0.09 \\
\hline MM & 19 & 6.28 & $6.0-6.5$ & 0.15 & 4 & 6.65 & $6.5-6.8$ & 0.13 & 4 & 6.54 & $6.35-6.64$ & 0.13 & 2 & 7.03 & $6.74-7.28$ & 0.18 \\
\hline $\mathrm{CM}^{3}$ & 19 & 5.89 & $5.7-6.1$ & 0.12 & 4 & 6.27 & $6.2-6.3$ & 0.05 & 4 & 6.42 & $6.29-6.59$ & 0.13 & 2 & 6.74 & $6.60-6.90$ & 0.10 \\
\hline $\mathrm{CM}_{3}$ & 19 & 6.22 & $6.0-6.4$ & 0.12 & 4 & 6.75 & $6.7-6.8$ & 0.06 & 4 & 6.82 & $6.74-6.96$ & 0.11 & 2 & 7.22 & $7.07-7.37$ & 0.11 \\
\hline $\mathrm{IM}^{3}$ & 19 & 7.25 & $7.1-7.5$ & 0.15 & 4 & 7.63 & & 0.29 & - & - & - & - & - & - & - & - \\
\hline $\mathrm{IM}_{3}$ & 19 & 7.67 & $7.5-8.0$ & 0.13 & 4 & 8.13 & $8.0-8.2$ & 0.10 & - & - & - & - & - & - & - & - \\
\hline HMD & 19 & 3.82 & $3.5-4.1$ & 0.18 & 4 & 4.03 & $3.8-4.2$ & 0.17 & - & - & - & - & - & - & - & - \\
\hline LMD & 19 & 11.77 & $11.3-12.2$ & 0.24 & 4 & 12.23 & $11.8-12.6$ & 0.33 & 4 & 11.93 & $11.8-12.1$ & 0.14 & 2 & 12.53 & $12.2-12.8$ & 0.20 \\
\hline
\end{tabular}

Note: $n$ - sampling size, $\mathbf{M}$ - average value (highlighted in bold font), min - minimal value, max - maximal value, SD - standard deviation.

Craniometric data of bats of the "Myotis nattereri» group were relatively well factorised. The first three principal components described $73.2 \%$ of the total variability. This indicates that there are differences in the skull proportion. The first two principal components explained the division of the sampling set of «Myotis nattereri» bat samples into two well-separated groups, which clearly correspond to M. cf. tschuliensis 2 and M. nattereri (Fig. 5). Their differen- tiation occurred exclusively based on the first principal component (eigenvalue: 8.34; total variance: $49.06 \%$ ) highly negatively correlated with the size of tooth rows $\left(\mathrm{CM}^{3}, \mathrm{CM}_{3}, \mathrm{IM}_{3}\right.$, $\left.\mathrm{IM}^{3}, \mathrm{MM}\right)$, zygomatic width (ZW), and neurocranium width (W) (Table 2). The second principal component (eigenvalue: 2.47; total variance: $14.55 \%$ ) was negatively correlated with palate length (PL), but it was not involved in the division of samples. 


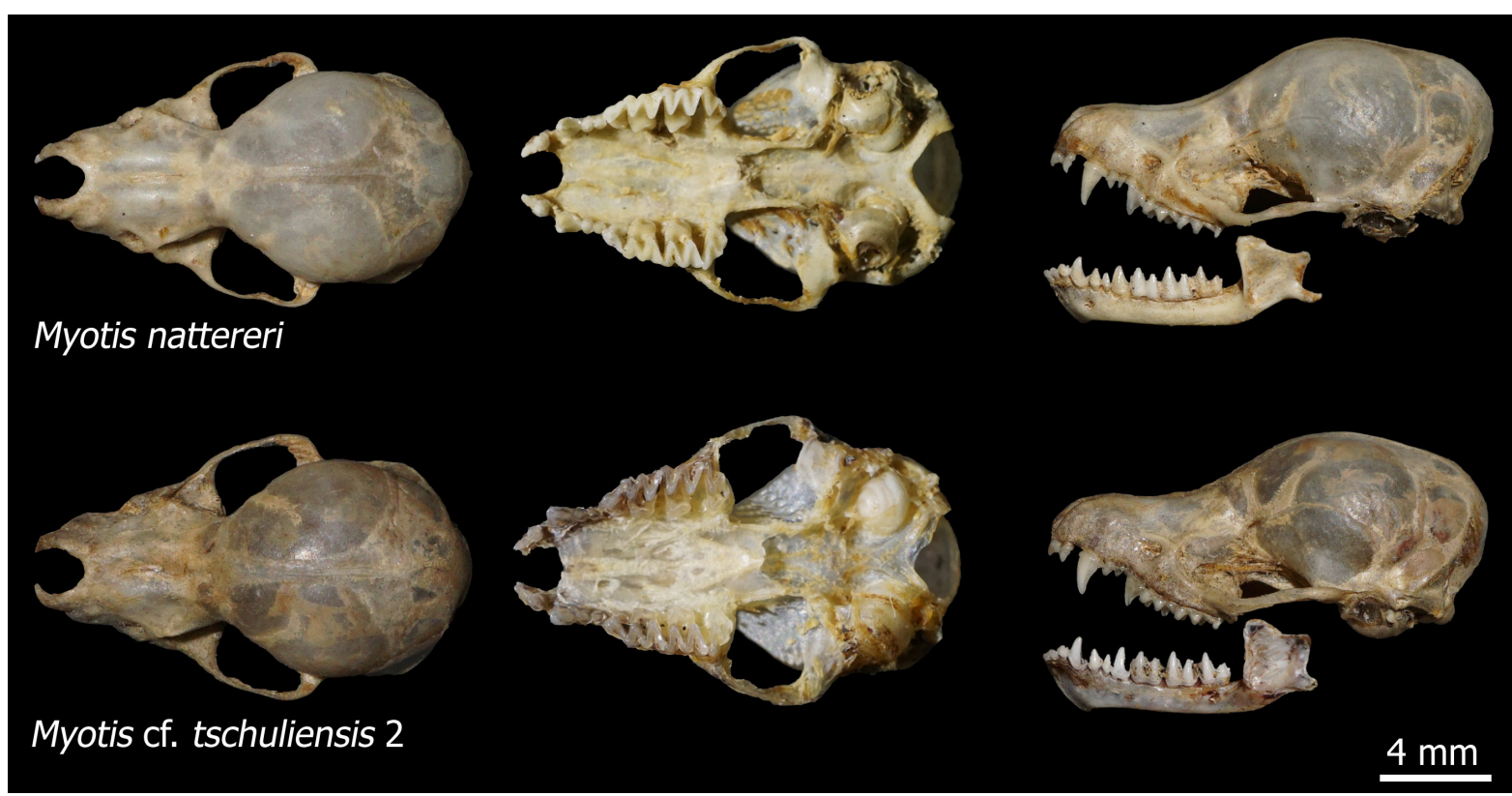

Fig. 4. Myotis nattereri skull (collection PSU: No. 861, adult female, Samara region) and M. cf. tschuliensis 2 (collection PSU: No. 1375, adult female, Dagestan).

Table 2. Factor loads of examined morphometric cranial traits

\begin{tabular}{l|ccccccccccccccccc}
\hline \multirow{2}{*}{$\begin{array}{c}\text { Principal } \\
\text { components }\end{array}$} & TL & CBL & ZW & MW & H & W & PL & WR & SW & CC & MM & $\mathrm{CM}^{3}$ & $\mathrm{CM}_{3}$ & $\mathrm{IM}^{3}$ & $\mathrm{IM}_{3}$ & $\mathrm{HMD}^{\mathrm{L}} \mathrm{LMD}^{\prime}$ \\
\hline PC1 & -0.52 & -0.74 & -0.83 & -0.61 & -0.16 & -0.83 & 0.16 & -0.73 & -0.06 & -0.63 & -0.82 & -0.90 & -0.93 & -0.82 & -0.90 & -0.60 & -0.75 \\
$\mathrm{PC} 2$ & -0.54 & -0.47 & -0.01 & -0.39 & 0.09 & -0.09 & -0.86 & 0.30 & 0.11 & 0.71 & 0.30 & -0.15 & -0.13 & -0.12 & -0.13 & 0.50 & -0.24 \\
\hline
\end{tabular}

For discriminant analysis, the total data set was divided into three training sample groups, including «M. nattereri males», «M. nattereri females» and «M. cf. tschuliensis 2». Unfortunately, the third one included small number samples, which does not exclude some distortion of the results. The analysis was carried out using the stepwise selection method. On its basis, we excluded 11 out of 17 cranial traits as insignificant ones. The classification procedure confirmed the pronounced morphological isolation of the specimens designated as M. cf. tschuliensis 2 (Fig. 6). On the basis of the first two discriminant functions (in total, they describe $100 \%$ of the total dispersion), they formed a cluster well separated from the groups «M. nattereri males» and «M. nattereri females». The division is predominantly based on the first discriminant function. Its Wilks lambda value is about zero (Table 3 ). This indicates the best discrimination and adequacy of the model. $\mathrm{CM}_{3}$ and WR had the highest positive correlation with DF1. The second discriminant function had considerably lower influence to the division of samples. This function is negatively correlated with morphometric traits of $\mathrm{CC}$ and $\mathrm{CM}_{3}$. This function promotes the division of Myotis nattereri samples on groups of males and females. Despite females look slightly larger than males and in general, their formed dispersion clusters did not overlap (Table 4), there were no statistical differences between groups of males and females in terms of morphometric skull traits.

Myotis nattereri is characterised by a highly variable os penis shape (Fig. 7). Externally, it is a bony plate bent along the longitudinal axis with a well-defined groove in the bottom urethral. The distal end is raised above the base plane at about an angle of $45^{\circ}$. The majority of specimens has a well-defined clipping on the proximal part. The upper plate edge is often smooth, without deflections. In the centre of European Russia, individuals have a much larger os penis than animals from the Carpathian basin (Topál, 1958; Smirnov, 2000). In general, Dagestan bats' os penis is similar to the one in $M$. nattereri, while general sizes of their baculum (length: $0.825 \mathrm{~mm}$; maximal width: $0.5 \mathrm{~mm}$ ) are within the variability limits. However, unlike $M$. nattereri, in $M$. cf. tschuliensis 2, the dorsal surface of the os penis has a well-defined transverse (saddle-shaped) deflection and a relatively shallow proximal clipping $(0.075 \mathrm{~mm})$. 


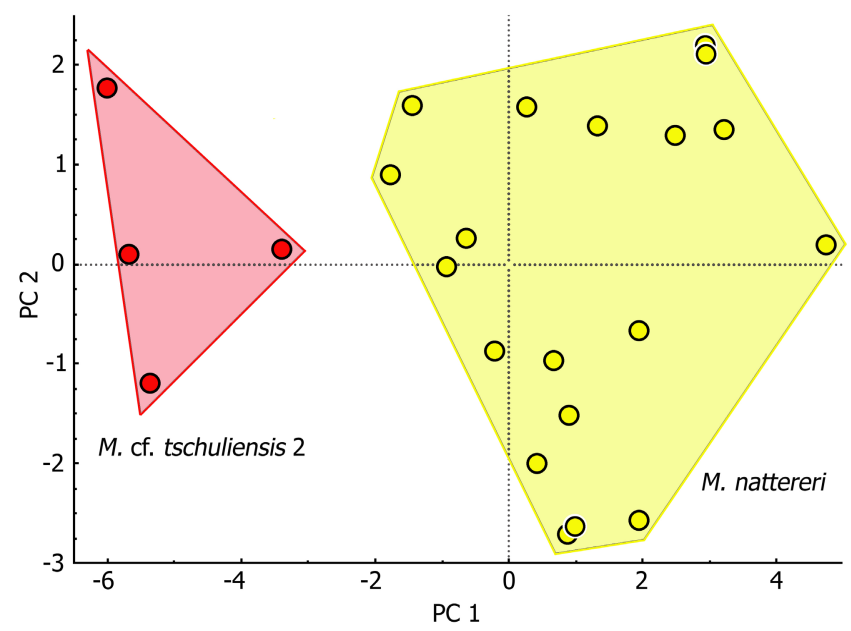

Fig. 5. Distribution of 23 bat specimens of the «Myotis nattereri» group on the basis of the first two principal components (PC1, PC2), calculated on the basis of 17 cranial traits.

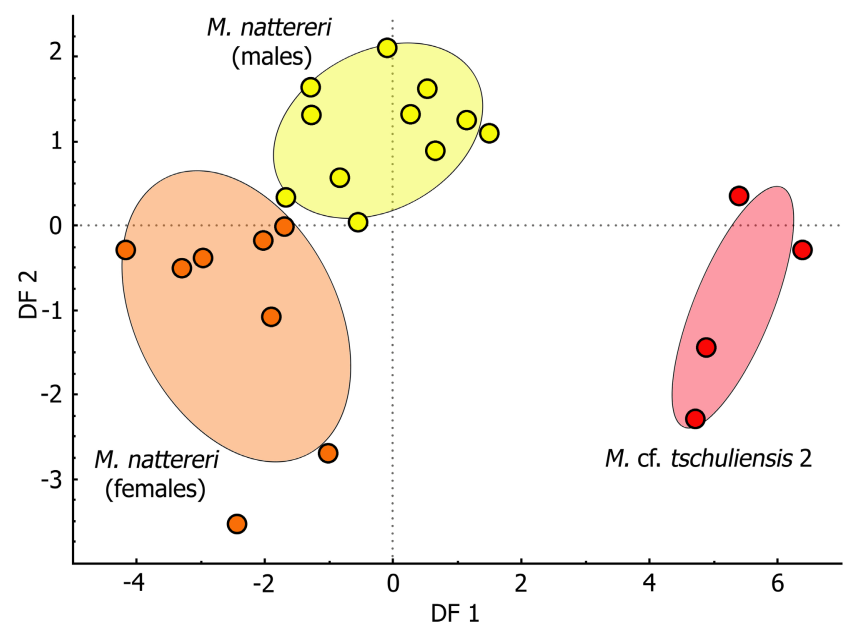

Fig. 6. Distribution of 23 bat specimens of the «Myotis nattereri» group on the basis of the first two discriminant functions (DF1 and DF2) calculated on the basis of six cranial traits included in the model.
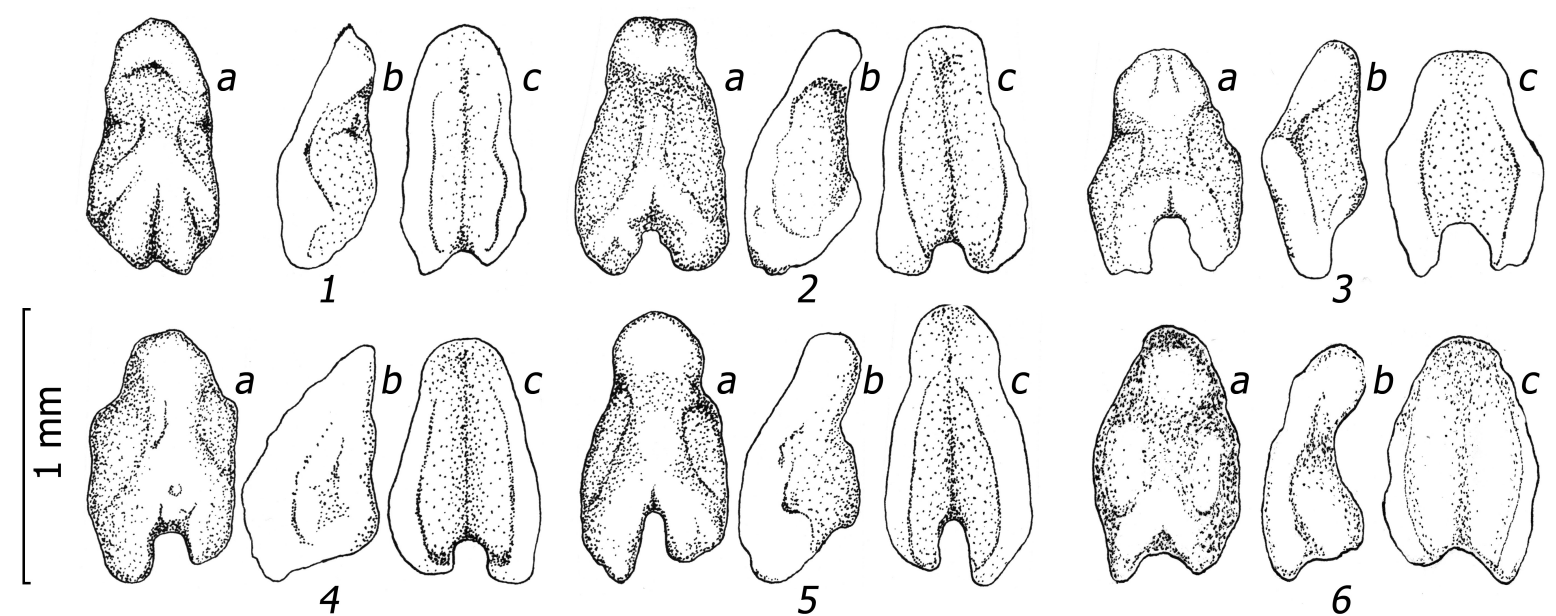

Fig. 7. Os penis of Myotis nattereri (1-5, collection PSU 509, 860, 862-864, Samara region) and M. cf. tschuliensis 2 (6, collection PSU 1377, Dagestan). Designations: $\mathrm{a}$ - dorsal side, $\mathrm{b}$ - lateral side, $\mathrm{c}$ - ventral side.

Table 3. Coefficients of combined intra-group correlation of cranial traits having the highest importance in intergroup differences on the basis of the two discriminant functions and results of their significance under step-by-step criterion

\begin{tabular}{c|cc}
\hline Cranial traits & DF1 & DF2 \\
\hline $\mathrm{CM}_{3}$ & 0.62 & -0.59 \\
$\mathrm{WR}$ & 0.44 & -0.11 \\
$\mathrm{CC}$ & 0.17 & -0.50 \\
$\mathrm{MM}$ & 0.34 & -0.18 \\
$\mathrm{CBL}$ & 0.22 & -0.08 \\
$\mathrm{SW}$ & 0.03 & -0.22 \\
\hline Wilks lambda $(\lambda)$ & 0.05 & 0.43 \\
\cline { 1 - 1 }$\chi^{2}$-test & 53.21 & 14.60 \\
\cline { 1 - 1 } Explained dispersion & 0.861 & 0.139 \\
\cline { 1 - 1 }$p$-level & $<0.0001$ & 0.012 \\
\hline
\end{tabular}

\section{Molecular data}

We studied 89 sequences from various forms in the complex of the M. nattereri s.l. Of them, 15 sequences were original (seven ones are from
Table 4. Significance of differences ( $p$-levels) in the centroid position (above the diagonal) and the values of squared Mahalanobis distances (under the diagonal) between three bat samples of the «Myotis nattereri» group calculated using Discriminant Analysis of six cranial traits included in the model

\begin{tabular}{|c|c|c|c|}
\hline Group & $\begin{array}{c}\text { Myotis natterer } \\
\text { males }\end{array}$ & $\begin{array}{l}\text { Yyotis nattereri } \\
\text { females }\end{array}$ & $\begin{array}{c}\text { Myotis } \mathrm{cf} . \\
\text { tschuliensis } 2\end{array}$ \\
\hline $\begin{array}{l}\text { Myotis nattereri } \\
\text { males }\end{array}$ & - & 0.002678 & 0.000043 \\
\hline $\begin{array}{l}\text { Myotis nattereri } \\
\text { females }\end{array}$ & 60.48000 & - & 0.000002 \\
\hline $\begin{array}{l}\text { Myotis cf. } \\
\text { tschuliensis } 2\end{array}$ & 34.11091 & 10.02886 & - \\
\hline
\end{tabular}

the Republic of Dagestan, one from Penza region, one from the Republic of Mordovia, six from Samara region). The remaining ones were extracted from GenBank. Phylogenetic trees ob- 
tained using the neighbour-joining, maximum likelihood, and Bayesian approach methods demonstrated the same topology (Fig. 8). Most clades had a high support. Their phylogenetic reconstruction were relatively similar to the mitochondrial constructions published earlier (e.g., Ibáñez et al., 2006; Salicini et al., 2011, 2013; Puechmaille et al., 2012; Çoraman et al., 2019; Juste et al., 2019).

The phylogenetic tree is divided into two large clades. Each of them contains several lines o species level. The first clade includes a branch of $M$. nattereri s.str. with lines from West Europe and Central Russia, which, in general, have low genetic differences $(2.4 \pm 0.5 \%)$. The West Asian and Caucasian samples are included in the second clade. In this clade, a separate group is formed by
M. schaubi and specimens from Turkey and Syria designated as $M$. cf. tschuliensis 1 . The genetic distance between them varied from 3.8 to $5.2 \%$. Dagestan samples designated as $M$. cf. tschuliensis 2 formed a branch sister to the ones mentioned above. This branch is separated from M. schaubi and $M$. cf. tschuliensis 1 specimens with a high support and a large genetic gap from each sample $(7.4 \pm 1.0$ and $7.0 \pm 0.8 \%$, respectively).

The haplotype network supports the division of the clades of $M$. nattereri s.str. and M. schaubi/ cf. tschuliensis into intragroup lines (Fig. 9). The first of them is separated into West European and Russian haplogroups. The second one separates the haplogroup of $M$. cf. tschuliensis 2 from the ones of M. schaubi and M. cf. tschuliensis 1 by a long branch.

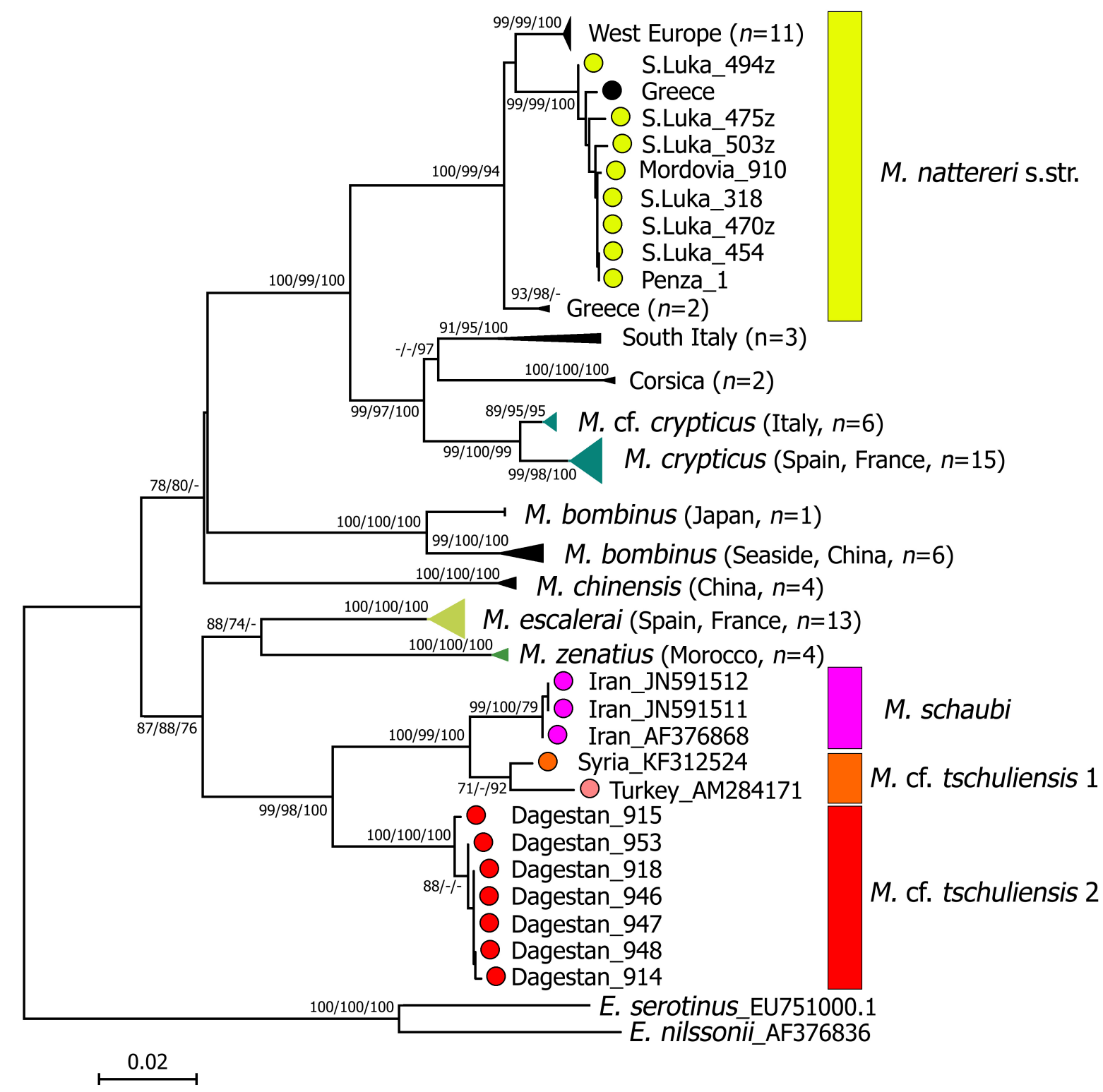

Fig. 8. Dendrogram of phylogenetic relationships of species forms in the complex of Myotis nattereri s.l. on the basis of analysis of cytb gene sequences $(1140 \mathrm{bp})$ using the neighbour-joining method. The numbers in the nodes indicate the level of bootstrap support. Bayesian posterior probabilities are above $70 \%$ in neighbour-joining/maximum likelihood/Bayesian analysis analyses. 


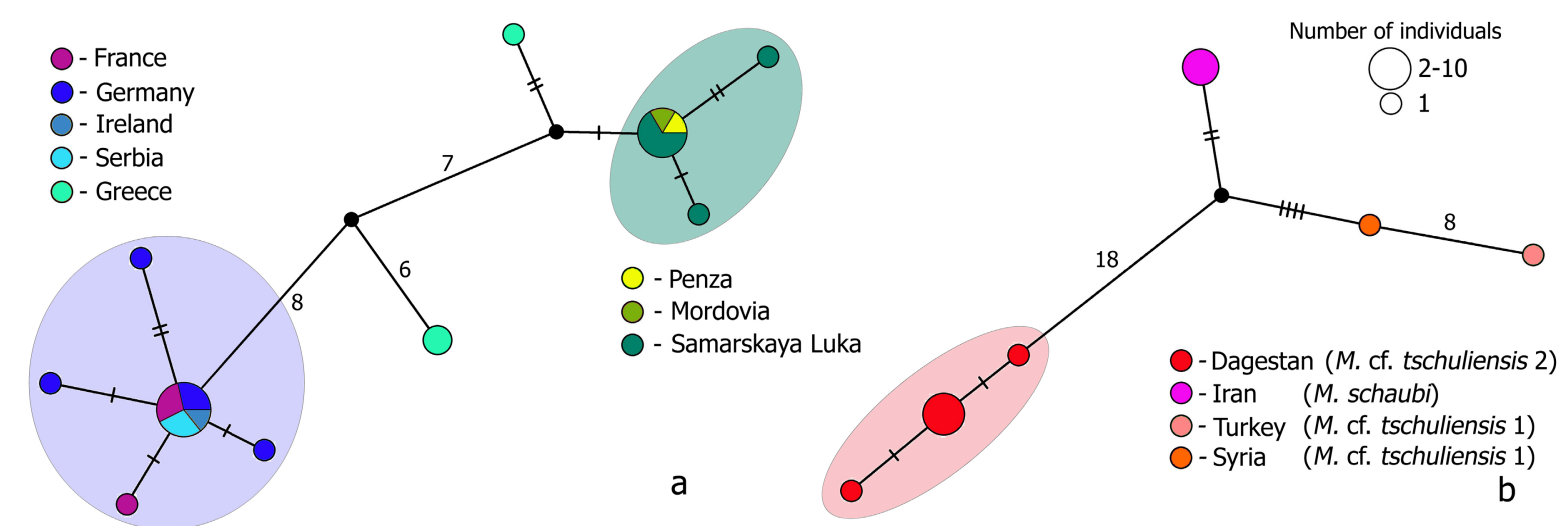

Fig. 9. Median haplotype networks constructed on the basis of sequences ( $699 \mathrm{bp}$ ) of the cytb gene groups of Myotis nattereri s.str. (a) and M. schaubi/cf. tschuliensis (b). Transverse strokes and numbers on the branches show the number of mutational events. The colours denote samples with various geographical affiliations. The circle size is proportional to the number of individuals, and the fractions are proportional to the frequencies of samples per haplotype.

\section{Discussion}

The research results of morphological and genetic analyses showed significant differences in $M$. nattereri s.l. between specimens from Central Russia and from the Eastern Caucasus. Despite a considerable similarity in external morphological traits, Caucasian specimens have a larger skull. The lengths of upper and lower tooth rows are especially recognisable, which claim to be considered as species-specific traits in terms of differentiation level. Collection samples could be easily identified on the basis of these cranial traits, as well as using the method of discriminant analysis under the presence of learning samplings. The existence of a gap at the species level confirms the results of mtDNA analysis. The studied phylogeneic groups, $M$. cf. tschuliensis 2 and $M$. nattereri s.str., were separated in different clades. They are represented by unrelated lines, while the pairwise genetic distances calculated for them (from $16.0 \%$ to $16.7 \%$ ) significantly exceeded the interspecific thresholds in accordance with the test developed for mammals under the genetic concept of a species (Baker \& Bradley, 2006). The long-term spatial isolation of the Caucasian part of the species range could be an additional evidence of the species independence of $M$. cf. tschuliensis 2 . This area may have been a refugium for this form, like West Balkans, Greece, and West Anatolia, which Çoraman et al. (2019) already mentioned before. At the same time, the northern part of the species range was most likely formed in the post-glacial period due to the expansion of individuals from South-East Europe into this area. The ingress of one haplotype from Greece into the group of haplotypes from Central Russia could be a confirmation of this hypothesis (Fig. 6, Fig. 7). It is possible that this similarity is a result of the former hybridisation with subsequent introgression of Balkan genes into the genotype of the populations dispersed from West Europe to East Europe in the post-glacial period. Two of the Greek samples form a separate genetic line occupying a basal position to the main group of the $M$. nattereri s.str. samples. The diversity of genetic lines observed in the Caucasus, as well as in the Balkans, may indicate an ancient origin of these parts of the species range (Kerth et al., 2008; Bogdanowicz et al., 2009).

To which species the Dagestan samples belong is not clear yet. Two more forms, i.e. $M$. schaubi and $M$. cf. tschuliensis 1, are known from the Caucasus and in the area located south of it, i.e. Turkey, Georgia, Iran, Turkmenistan. Myotis schaubi has the largest size, and differs highly in the size of the body and skull (Table 1). According to Horáček \& Hanák (1984), M. schaubi $(=M$. araxenus Dahl, 1947) is endemic to the Caucasus region. Its distribution is limited to a small area within Armenia and Iran (Horáček et al., 2000; Benda et al., 2012). Myotis cf. tschuliensis 1 is much smaller in terms of the size of body and skull, compared to M. schaubi, but nevertheless it looks larger than $M$. nattereri s.str. This form was originally described as a subspecies, M. n. tschuliensis (Kuzyakin, 1935), on the basis of specimens collected by S.I. Ognev in the Chuli gorge north-west of Kopet-Dag in 1925 (Ognev, 1928). Noteworthy, S.I. Ognev considered these specimens as representatives of another taxon: M. emarginatus desertorum Dobson, 1876. Its further records in Azerbaijan, East Turkey, Armenia, Georgia, and Crimea were formally associated with «tschuliensis» on the basis of morphological analysis, without analysing the type specimens. Phylogenetic reconstructions of sequences of their mitochondrial and nuclear genes made it possible to consider this form as a separate species (e.g., Benda et al., 2006, 2011; Jones et al., 2006; Çoraman et al., 2019). According to these studies, M. schaubi and M. cf. tschuliensis 
are two closely related lineages, which have a clearly pronounced contact zone in Armenia in the absence of introgressive events and intermediate phenotypes (Benda et al., 2006; Çoraman et al., 2019). Thus, it is assumed that $M$. cf. tschuliensis should occupy a fairly extensive range, covering areas of the Crimea, Caucasus, Transcaucasia, East Turkey, and Turkmenistan.

According to a cranial trait analysis, Dagestani bats designated as $M$. cf. tschuliensis 2 are closely related to $M$. cf. tschuliensis 1 (Table 1). However, we did not find the qualitative traits of the skull structure described by Kuzyakin (1935) for individuals from Koped-Dag as distinct from the nominative form (strongly narrowed neurocranium, relatively narrowed and elongated nasal section). Kuzyakin (1950) pointed out that on the basis of the mentioned cranial traits the skull of the Kopet-Dagoriginated form is more similar to the skull of $M$. emarginatus compared to the forms of $M$. nattereri.

In contrary to $M$. nattereri s.str., Dagestan bats, similar to $M$. cf. tschuliensis 1 , were found in extremely arid habitats (Fig. 10) (Smirnov et al., 2019b). We found seven brood colonies with a total number of 50 individuals. As a rule, colonies were represented by groups consisted of one to seven bat individuals in vertically arranged iron drainage pipes with a diameter of up to $5 \mathrm{~cm}$, immured in concrete slabs of various buildings. In the cluster «Sarykum dunes» of the Dagestan State Nature Reserve, the largest colony consisted of 15 individuals. In addition, two males were found separately from female individuals. An important factor for the successful inhabitation of this species in so arid conditions is probably the attractive feeding stations represented by pastures with a high exploitation load and extremely poor xerophytic tree-shrub vegetation. However, our molecular genetic studies demonstrated (Fig. 6, Fig. 7) that the analysed samples constituted a separate clade. This clade was quite distanced not only from $M$. schaubi $(7.4 \pm 1.0 \%)$, but also from the close line of $M$. cf. tschuliensis 1 from Turkey and Syria $(7.0 \pm 0.8 \%)$, with which specimens from Azerbaijan, Georgia and Crimea are provisionally combined (Çoraman et al., 2019). At the same time, the taxonomic position of bats from mixed and broad-leaved forests of the West Caucasus remains unclear. Such a situation indicates the probable presence of hidden diversity among the forms of this species group in the mentioned area. However, under the absence of genetically typed specimens from the type locality of $M$. tschuliensis, it is impossible to make any conclusions about its taxonomic position. Therefore, we suggest using the name «M. cf. tschuliensis» for Dagestan bats, like for all specimens of this species from the steppe areas of the East Caucasus and Crimea until this issue is clarified. These specimens are presumably more genetically differentiated from $M$. schaubi than from specimens from Turkey, which are associated with $M$. tschuliensis, too. This serves as an additional argument in favour of their independence as a species. On the other hand, this fact indicates the need for additional investigations, including molecular genetic studies involving both mitochondrial and nuclear genes. If we find that $M$. cf. tschuliensis individuals from Transcaucasia, East Turkey, and Georgia are genetically identical to its specimens from the type locality, then the Dagestan bats should be described as a new species.

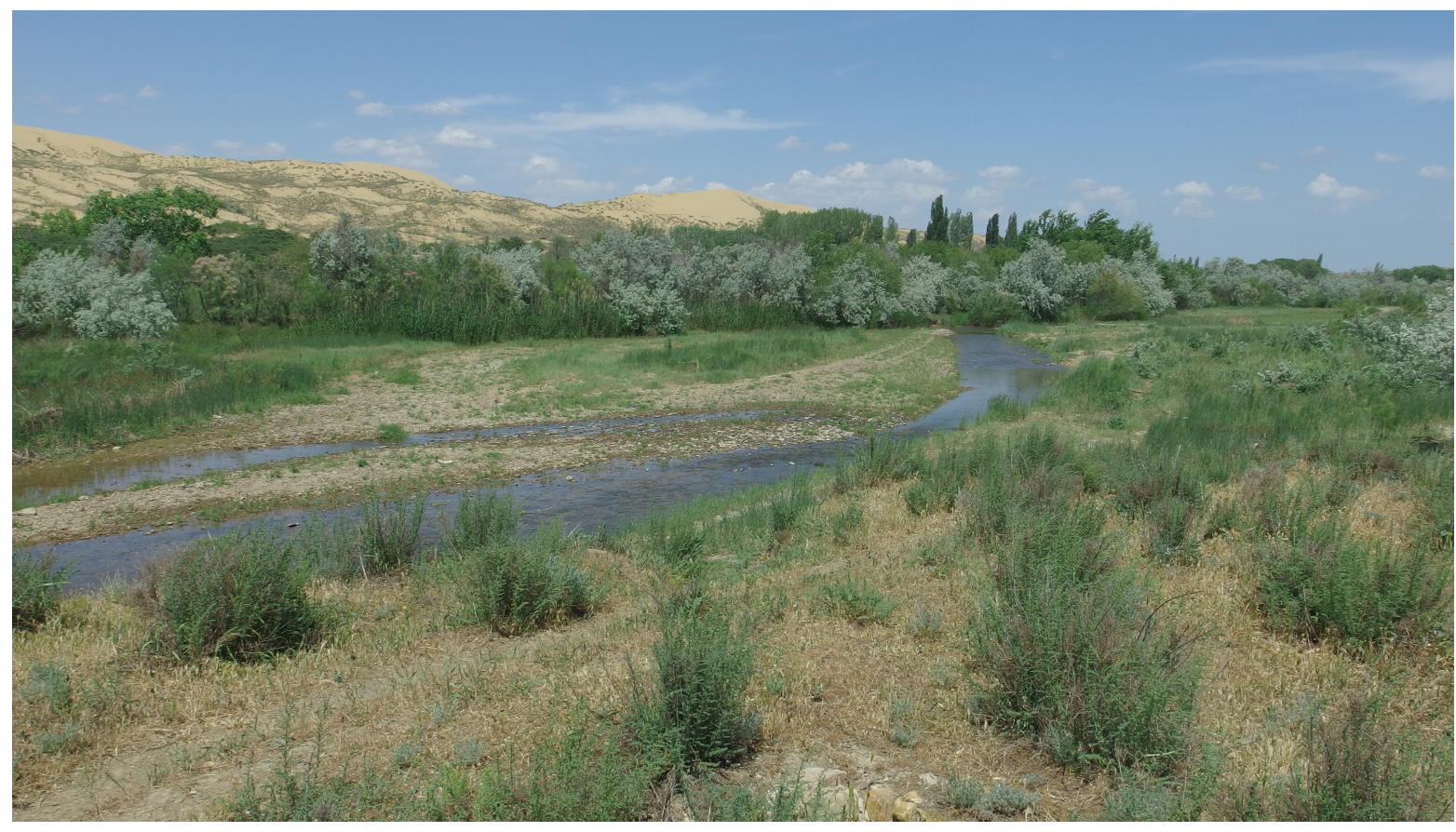

Fig. 10. Shura-Ozen River valley. Place of Myotis cf. tschuliensis 2 inhabitation. 


\section{Conclusions}

The study has demonstrated that the representatives of the Myotis nattereri complex from Central Russia and the East Caucasus are not identical. The identified morphological and genetic differences demonstrated their isolation at the species level. Caucasian specimens were close to the previously isolated West Asian (Eastern Turkey, Azerbaijan, Crimea) M. cf. tschuliensis 1 forms. Myotis cf. tschuliensis 2 has a larger skull size compared to the $M$. nattereri s.str. skull, but smaller than the M. schaubi skull. Distinctive features were a deep clipping in the upper half of the posterior ear edge; attachment of the posterior edge of the wing membrane on the very base of the outer finger; cilia on the uropatagium are almost twice the length of the bristles; a welldefined transverse (saddle-shaped) deflection of the os penis. In addition, $M$. cf. tschuliensis individuals do not have a narrowed neurocranium nor a strongly elongated and narrowed nasal section, compared to the type specimens from Kopet-Dag (Turkmenistan). The uniqueness of Dagestan bats is supported by phylogenetic constructions based on sequences of the cytb mitochondrial gene (Fig. 8). The genetic distances between $M$. cf. tschuliensis 2 and $M$. nattereri s.str. are from $16.0 \%$ to $16.7 \%$, while the genetic distances between Dagestan bats and samples from Turkey and Syria are 7.0-7.4\%.

We suggest keeping the same name for the East Caucasian forms (Myotis cf. tschuliensis) until genetic studies of the type specimens from Turkmenistan (Kopet-Dag) are carried out. If it is found that the West Asian M. cf. tschuliensis are genetically identical to the specimens from the type locality (Kopet-Dag, Turkmenistan), then the Dagestan bats should be described as a new species.

\section{References}

Artaev O.N., Smirnov D.G. 2016. The bats (Chiroptera; Mammalia) of Mordovia: specific structure and features of distribution. Nature Conservation Research 1(1): 38-51. DOI: 10.24189/ncr.2016.004 [In Russian]

Baker R.J., Bradley R.D. 2006. Speciation in mammals and the genetic species concept. Journal of Mammalogy 87(4): 643-662. DOI: 10.1644/06-MAMM-F-038R2.1

Benda P., Andreas M., Kock D., Lučan R.K., Munclinger P., Nová P., Obuch J., Ochman K., Reiter A., Uhrin M., Weinfurtová D. 2006. Bats (Mammalia: Chiroptera) of the Eastern Mediterranean. Part 4. Bat fauna of Syria: distribution, systematics, ecology. Acta Societatis Zoologicae Bohemicae 70: 1-329.

Benda P., Hanák V., Červený J. 2011. Bats (Mammalia: Chiroptera) of the Eastern Mediterranean and Middle East. Part 9. Bats from Transcaucasia and West Turkestan in collection of the National Museum, Prague. Acta Societatis Zoologicae Bohemicae 75: 159-222.

Benda P., Faizolahi K., Andreas M., Obuch J., Reiter A., Ševčík M., Uhrin M., Vallo P., Ashraf S. 2012. Bats (Mammalia: Chiroptera) of the Eastern Mediterranean and Middle East. Part 10. Bat fauna of Iran. Acta Societatis Zoologicae Bohemicae 76: 163-582.

Benda P., Gazaryan S.V., Vallo P. 2016. On the distribution and taxonomy of bats of the Myotis mystacinus morphogroup from the Caucasus region (Chiroptera: Vespertilionidae). Turkish Journal of Zoology 40: 842-863. DOI: 10.3906/zoo-1505-47

Bogdarina S.V., Strelkov P.P. 2003. Distribution of bats (Chiroptera) in the north of European Russia. Plecotus et al. 6: 7-28. [In Russian]

Bogdanowicz W., Van Den Bussche R.A., Gajewska M., Postawa T., Harutyunyan M. 2009. Ancient and Contemporary DNA Sheds Light on the History of Mouse-Eared Bats in Europe and the Caucasus. Acta Chiropterologica 11(2): 289-305. DOI: 10.3161/150811009X485530

Clement M., Posada D., Crandall K.A. 2000. TCS: a computer program to estimate gene genealogies. Molecular Ecology 9(10): 1657-1659. DOI: 10.1046/j.1365294x.2000.01020.x

Çoraman E., Dietz C., Hempel E., Ghazaryan A., Levin E., Presetnik P., Zagmajster M., Mayer F. 2019. Reticulate evolutionary history of a Western Palaearctic bat complex explained by multiple mtDNA introgressions in secondary contacts. Journal of Biogeography 46(2): 343-354. DOI: 10.1111/jbi.13509

Darriba D., Taboada G.L., Doallo R., Posada D. 2012. jModelTest 2: more models, new heuristics and parallel computing. Nature Methods 9(8): 772. DOI: 10.1038/nmeth.2109

Frilei C.E. 1947. Preparation and preservation of the baculum of mammals. Journal of Mammalogy 28(4): 395 397. DOI: $10.2307 / 1375362$

García-Mudarra J.L., Ibáñez C., Juste J. 2009. The Straits of Gibraltar: barrier or bridge to Ibero-Moroccan bat diversity. Biological Journal of the Linnean Society 96(2): 434-450. DOI: 10.1111/j.1095-8312.2008.01128.x

Gazaryan S.V. 2002. Ecological-faunal analysis of bats (Chiroptera) in the West Caucasus. PhD Thesis. Moscow. 225 p. [In Russian]

Grimmberger E., Rudolf K. 2009. Atlas der Säugetiere Europas, Nordafrikas and Vorderasian. Münster: Natur und Tier Verl. 495 p.

Hall T.A. 1999. BioEdit: a user-friendly biological sequence alignment editor and analysis program for Windows 95/98/NT. Nucleic Acids Symposium Series 41: 95-98.

Horáček I., Hanak V. 1984. Comments on the systematics and phylogeny of Myotis nattereri (Kuhl, 1818). Myotis 21: $20-29$.

Horáček I., Hanák V., Gaisler J. 2000. Bats of the Palearctic region: a taxonomic and biogeographic review. In: B.W. Wołoszyn (Ed.): Proceedings of the VIII European Bat Research Symposium. Vol. 1: Approaches to Biogeography and Ecology of Bats. Kraków: Chiropterological Information Center, Institute of Systematics and Evolution of Animals PAS. P. 11-157. 
Ibáñez C., García-Mudarra J.L., Ruedi M., Stadelmann B., Juste J. 2006. The Iberian contribution to cryptic diversity in European bats. Acta Chiropterologica 8(2): 277-297. DOI: 10.3161/1733-5329(2006)8\%5B277:TI CTCD\%5D2.0.CO;2

Ilyin V.Yu., Smirnov D.G., Krasilnikov D.B., Yanaeva N.M. 2002. Materials to the cadastre of bats (Chiroptera) in European Russia and adjacent regions. Penza: Penza State Pedagogical University. 64 p. [In Russian]

Jones G., Parsons S., Zhang S., Stadelmann B., Benda P., Ruedi M. 2006. Echolocation calls, wing shape, diet and phylogenetic diagnosis of the endemic Chinese bat Myotis pequinius. Acta Chiropterologica 8(2): 451-463. DOI: 10.3161/1733-5329(2006)8[451:ECWSDA]2.0.CO;2

Juste J., Ruedi M., Puechmaille S.J., Salicini I., Ibáñez C. 2019. Two new cryptic bat species within the Myotis nattereri species complex (Vespertilionidae, Chiroptera) from the Western Palaearctic. Acta Chiropterologica 20(2): 285-300. DOI: 10.3161/15081109ACC2 018.20.2.001

Kerth G., Petrov B., Conti A., Anastasov D., Weishaar M., Gazaryan S., Jaquiéry J., König B., Perrin N., Bruyndonckx N. 2008. Communally breeding Bechstein's bats have a stable social system that is independent from the postglacial history and location of the populations. Molecular Ecology 17(10): 2368-2381. DOI: 10.1111/j.1365-294X.2008.03768.x

Kozhurina E.I. 2009. Conspectus of the Russian bat fauna: systematics and distribution. Plecotus et al. 11-12: 71105. [In Russian]

Kruskop S.V. 2012. Order Chiroptera. In: I.Ya. Pavlinov, A.A. Lissovsky (Eds.): Mammals of Russia: systematic and geographical handbook. Proceedings of the Zoological Museum of the Moscow State University. Vol. 52. P. 73-126. [In Russian]

Kumar S., Stecher G., Tamura K. 2016. MEGA7: Molecular Evolutionary Genetics Analysis Version 7.0 for Bigger Datasets. Molecular Biology and Evolution 33(7): 1870-1874. DOI: 10.1093/molbev/msw054

Kuzyakin A.P. 1935. New data on the taxonomy and geographical distribution of bats (Chiroptera) in USSR. Bulletin of Moscow Society of Naturalists 44(7-8): 428-438. [In Russian]

Kuzyakin A.P. 1950. Bats. Moscow: Sovetskaya nauka. 443 p. [In Russian]

Leigh J.W., Bryant D., Nakagawa S. 2015. POPART: fullfeature software for haplotype network construction. Methods in Ecology and Evolution 6(9): 1110-1116. DOI: 10.1111/2041-210x.12410

Mayer F., Dietz C., Kiefer A. 2007. Molecular species identification boosts bat diversity. Frontiers in Zoology 4: 4 . DOI: 10.1186/1742-9994-4-4

Ognev S.I. 1928. Mammals of East Europe and Northern Asia. Vol. 1. Moscow; Leningrad: Gospolitizdat. 631 p. [In Russian]

Pavlinov I.Ya., Kruskop S.V., Varshavskiy A.A., Borisenko A.V. 2002. Terrestrial mammals of Russia. Handbook-determinant. Moscow: KMK Scientific Press Ltd. 298 p. [In Russian]
Puechmaille S.J., Allegrini B., Boston E.S., Dubourg-Savage M.J., Evin A., Knochel A., Le Bris Y., Lecoq V., Lemaire M., Rist D., Teeling E.C. 2012. Genetic analyses reveal further cryptic lineages within the Myotis nattereri species complex. Mammalian Biology 77(3): 224-228. DOI: 10.1016/j.mambio.2011.11.004

Red Data Book of the Republic of Crimea. Animals. Simferopol: IT ARIAL, 2015. 440 p. [In Russian]

Ronquist F., Huelsenbeck J.P. 2003. MRBAYES 3: Bayesian phylogenetic inference under mixed models. Bioinformatics 19(12): 1572-1574. DOI: 10.1093/bioinformatics/btg180

Ruedi M., Mayer F. 2001. Molecular systematics of bats of the genus Myotis (Vespertilionidae) suggests deterministic ecomorphological convergences. Molecular Phylogenetics and Evolution 21(3): 436-448. DOI: 10.1006/mpev.2001.1017

Salicini I., Ibáñez C., Juste J. 2011. Multilocus phylogeny and species delimitation within the Natterer's bat species complex in the Western Palearctic. Molecular Phylogenetics and Evolution 61(3): 888-898. DOI: 10.1016/j.ympev.2011.08.010

Salicini I., Ibáñez C., Juste J. 2013. Deep differentiation between and within Mediterranean glacial refugia in a flying mammal, the Myotis nattereri bat complex. Journal of Biogeography 40(6): 1182-1193. DOI: 10.1111/jbi.12062

Sambrook J., Fritsch E.F., Maniatis T. 1989. Molecular Cloning: A Laboratory Manual. New York: Cold Spring Harbor Laboratory Press. 1546 p.

Sikes R.S., Gannon W.L. 2011. Guidelines of the American Society of Mammalogists for the use of wild mammals in research. Journal of Mammalogy 92(1): 235-253. DOI: 10.1644/10-MAMM-F-355.1

Simmons N.B. 2005. Order Chiroptera. In: D.E. Wilson, D.M. Reeder (Eds.): Mammal species of the World: a taxonomic and geographic reference. Baltimore: Johns Hopkins University Press. P. 312-529.

Smirnov D.G. 2000. Variability of bakulum in bats (Chiroptera, Vespertilionidae) in the Middle Volga region and adjacent areas. Plecotus et al. 3: 20-34. [In Russian]

Smirnov D.G., Dzhamirzoev G.S., Gazaryan S.V., Vekhnik V.P., Bykov Yu.A. 2019a. Bats (Chiroptera) of Dagestan: review of fauna resulted from research in 2017 2019. Plecotus et al. 22: 3-48. [In Russian]

Smirnov D.G., Vekhnik V.P., Dzhamirzoev G.S., Bykov Yu.A. 2019b. New data on the distribution of bats (Chiroptera) in the flat part of the Republic of Dagestan. Russian Journal of Ecosystem Ecology 4(4). DOI: 10.21685/2500-0578-2019-4-5 [In Russian]

Snitko V.P. 2011. Naterrer's bat (Myotis nattereri) at its eastern range boundary (the Urals). Zoologicheskii Zhurnal 90(10): 1245-1254. [In Russian]

Topál G. 1958. Morphological studies on the os penis of bats in the Carpathian Basin. Annales Musei Historico-Naturalis Hungarici 50(Series nova 9): 331-342.

White J. 1951. A Practical Method for Mounting the Bacula of Small Mammals. Journal of Mammalogy 32(1): 125. DOI: 10.1093/jmammal/32.1.125 
Appendix 1. List of samples used in morphological studies of the skull.

Myotis nattereri. Samara region: Zhigulevskiy urban district, 25.11.1995, $3 \mathrm{~mm}$ ad, $1 \mathrm{f}$ ad (PSU: 584, 586, 587, 589); Samara region: Zhigulevskiy urban district: $15.11 .1996,6 \mathrm{~mm}$ ad, $6 \mathrm{ff}$ ad (PSU: 858, 859, 860, $861,862,863,864,865,866,867,868,867)$; Samara region: Zhigulevskiy urban district: $21.03 .1998,1 \mathrm{~m}$ ad,
1 f ad (PSU: 1003, 1004); Republic of Bashkortostan, Abzelilovskiy district, 24.06.1997, $1 \mathrm{~m}$ ad (PSU: 902).

Myotis cf. tschuliensis. Republic of Dagestan: Kumtorkalinskiy district, 06.09.2019, $1 \mathrm{~m}$ ad (PSU: 1377), 2 ff ad (PSU: 1375, 1376); Republic of Dagestan: Kayakentsky region, 09.09.2019, 1 fad (PSU: 1378).

Appendix 2. List of samples used in molecular genetic studies on the basis of data from GenBank.

Myotis nattereri. Germany: DQ120893, DQ120894, DQ120895, DQ120892, JF412399; France: JF412396, JF412398, JF412401; Ireland: JF412400; Greece: JF412402, AF246261, AF376863; Serbia: JN591507, JN591508.

Myotis crypticus. Spain: DQ120884, DQ120885, DQ120886, MK214766, MK214767, MK214768, MK214769, MK214770; France: JX826327， JX826329， JX826330，JX826332， JF412409, JF412410, JF412411; Italy: JN591493, JN591497, JN591498, JN591499, JX826333, JX826340.

Myotis cf. crypticus. Italy: JN591495, JN591496, JN591494.

Myotis cp. C. Corsica: JF412413, JF412414.
Myotis escalerai. Spain: JX826288, JX826290, JX826292, JX826293， JX826296, JX826297, DQ120887, DQ120888, DQ120889, DQ120890, DQ120891; France: JF412390, JF412391.

Myotis zenatius. Morocco: MK214771, MK214772, MK214773, MK214774.

Myotis cf. tschuliensis. Turkey: AM284171; Syria: KF312524.

Myotis schaubi. Iran: JN591511, JN591512, AF376868.

Myotis bombinus. Russia: MG897532, MG897533, KF312503; China: KX467609, EF555239, EF555240; Japan: AB106606.

Myotis chinensis. China: EF555227, EF555228, JX465368, AB106588.

\title{
О ТАКСОНОМИЧЕСКОМ СТАТУСЕ НОЧНИЦ ИЗ ГРУППЫ ВИДОВ «MYOTIS NATTERERI» (CHIROPTERA, VESPERTILIONIDAE) НА ВОСТОЧНОМ КАВКАЗЕ
}

\author{
Д. Г. Смирнов ${ }^{1, *}$, В. П. Вехник ${ }^{2}$, Г. С. Джамирзоев ${ }^{3,4}$, С. В. Титов ${ }^{1}$ \\ ${ }^{1}$ Пензенский государственный университет, Россия \\ *e-mail: eptesicus@mail.ru \\ 2Жигулевский государственный природный биосферный заповедник имени И.И. Спрыгина, Россия \\ e-mail:vekhnik@mail.ru \\ ${ }^{3}$ Институт экологии горных территорий имени А.К. Темботова РАН, Россия \\ ${ }^{4}$ Дагестанский государственный природный заповедник, Россия \\ e-mail:dzhamir@mail.ru
}

\begin{abstract}
В последнее десятилетие на территории России Myotis nattereri рассматривали как монотипический вид, имеющий два очага обитания: северный - в средней полосе России и на Урале, и южный - на Кавказе и в Крыму. На основании морфологических и молекулярно-генетических данных обсуждается таксономический статус кавказских форм. На Восточном Кавказе (Республика Дагестан) были пойманы ночницы из группы видов «Myotis nattereri», по промерам черепа сходные с переднеазиатскими Myotis cf. tschuliensis. По внешним признакам дагестанские особи сходны с экземплярами из средней полосы России. Однако они имеют небольшие отличия в строении уха, бакулюма, характере крепления края крыловой перепонки к ступне и в соотношении длины ресничек к щетинкам на свободном крае межбедренной перепонки. Более надежные отличия от $M$. nattereri s.str. выявлены по результатам краниометрических исследований, а окончательное подтверждение видовой обособленности кавказских экземпляров дал анализ последовательностей мтДНК. Согласно филогенетическим построениям, экземпляры из Дагестана, обозначенные нами как Myotis cf. tschuliensis 2, формирует хорошо обособленную сестринскую линию по отношению к кладе кавказских форм: M. schaubi и M. cf. tschuliensis 1 ( $p$-расстояние: 7.4-7.0\%). Между тем, у M. cf. tschuliensis 2 и M. cf. tschuliensis 1 явных морфологических отличий нет. До проведения генетических исследований типовых экземпляров M. tschuliensis мы предлагаем использовать для восточнокавказской формы открытую номенклатуру. Если будет установлено, что M. cf. tschuliensis 1 с Ближнего Востока генетически идентичен экземплярам из типового места описания (Туркмения), то ночниц из Дагестана (M. cf. tschuliensis 2) следует считать новым неописанным видом.
\end{abstract}

Ключевые слова: Myotis cf. tschuliensis, Дагестан, криптический вид, ночница Наттерера, таксономия 